\title{
Mineral Composition of Three Perennial Grasses in a Shrub-Steppe Community in South-Central Washington
}

\section{DANIEL W. URESK AND JOHN F. CLINE}

Highlight: Cusick bluegrass, Thurber needlegrass, and bluebunch wheatgrass tissues, live and standing dead, were chemically analyzed in pastures with and without a history of cattle grazing. Two years of spring grazing by cattle did not affect the mineral composition of these grasses. Live herbage was generally richer in minerals than standing dead herbage, but ash content of standing dead tissues was always higher.

The forage resources of rangelands are an important commodity encountered by herbivores. Since herbivores are the primary harvesters of forage, it becomes important to know the nutritional quality of the important forage plants. I'hree perennial grasses, bluebunch wheatgrass (Agropyron spicatum), Cusick bluegrass (Poa cusickii), and Thurber needlegrass (Stipa thurberiana), were analyzed for mineral content in a stand of the Artemisia tridentata/Agropyron spicatum association in south-central Washington (Daubenmire, 1970).

McIlvanie (1942) found that nitrogen in bluebunch wheatgrass decreased $53 \%$ when clipped at hiweekly intervals.

Authors are with the Ecosystems Department, Battelle, Pacific Northwest Laboratories, Richland, Washington 99352.

Work performed under contract AT(45-1)-1830 with the United States Energy Research and Development Administration and National Science Foundation Grant GB-31862X2 to the Grassland Biome, U.S. International Biological Program for "Analysis of structure, function, and utilization of grassland ecosystems."

Manuscript received August 11, 1975.
Stoddart (1946) reported a steady decline of nitrogen and phosphorus with seasonal progression, but clipped herbage was generally higher in chemical constituents than unclipped herbage. A review concerning grazing and mineral analyses is presented by Jameson (1963).

The purpose of this study was to determine if cattle grazing would change the mineral composition of important forage plants in a shrub-steppe region of south-central Washington.

\section{Methods and Materials}

The study area is located on the Arid Lands Ecology (ALE) Reserve, situated within the confines of the Encrgy Rescarch and Development Administration's Hanford Reservation (Rickard et al., 1975). The soil is a silt loam with very few stones in the upper meter of its profile. Precipitation during the growing season, October to May, averaged $23 \mathrm{~cm}$ over a three-year period. Prior to the initiation of this study in 1971, there had been little or no cattle grazing since 1943.

One 9-ha pasture was moderately grazed by cattle during the spring for two consecutive years, 1971 and 1972, and allowed to recover in 1973. An adjacent ungrazed 9-ha area that had not been grazed by large herbivores for over 30 years, was used as a control. Eight replicates, $15 \times 30 \mathrm{~m}$, were located at random within both study areas. A single clump of the three perennial species from each replicate was clipped at ground level for mineral analyses when each species was in the phenological phase of seed development. Live herbage was 
Table 1. Average mineral composition of three perennial grasses for live and dead tissues on the Arid Lands Ecology (ALE) Reserve in south-central Washington.

\begin{tabular}{|c|c|c|c|c|c|c|}
\hline \multirow{2}{*}{$\begin{array}{l}\text { Mineral } \\
\text { analyses }\end{array}$} & \multicolumn{2}{|c|}{$\begin{array}{l}\text { B luebunch } \\
\text { wheatgrass }\end{array}$} & \multicolumn{2}{|c|}{$\begin{array}{c}\text { Cusick } \\
\text { bluegrass }\end{array}$} & \multicolumn{2}{|c|}{$\begin{array}{c}\text { Thurber } \\
\text { needlegrass }\end{array}$} \\
\hline & Live & Dead & Live & Dead & Live & Dead \\
\hline $\mathrm{N} \quad(\%)$ & $0.96^{*}$ & 0.63 & $1.78 *$ & * 1.15 & $1.03^{*}$ & $* 0.69$ \\
\hline $\mathrm{P} \quad(\%)$ & $0.17 *$ & 0.10 & $0.23^{*}$ & * 0.13 & 0.17 & - \\
\hline $\mathrm{K} \quad(\%)$ & $0.93 *$ & * 0.17 & 1.68 * & * 0.16 & $1.05 *$ & * 0.25 \\
\hline$S \quad(\%)$ & 0.12 & 0.13 & 0.20 * & * 0.16 & $0.17 *$ & * 0.25 \\
\hline $\mathrm{Mg}(\%)$ & $0.10^{*}$ & ${ }^{*} 0.07$ & $0.24 *$ & * 0.10 & 0.12 & 0.12 \\
\hline $\mathrm{Ca}(\%)$ & 0.39 & 0.30 & $0.81 *$ & $* 0.43$ & 0.50 & - \\
\hline $\mathrm{Na} \quad(\%)$ & 0.03 & 0.02 & 0.03 & 0.04 & 0.02 & 0.01 \\
\hline Ash (\%) & $9 *$ & 15 & $14^{*}$ & 20 & $11^{*}$ & 21 \\
\hline $\mathrm{Mn}(\mathrm{ppm})$ & 61 & 55 & 36 & 52 & 74 & 53 \\
\hline B $\quad(p p m)$ & $10^{*}$ & 5 & $18 *$ & 8 & $10 *$ & 6 \\
\hline $\mathrm{Cu} \quad(\mathrm{ppm})$ & 2 & 3 & 4 & 7 & 3 & - \\
\hline $\mathrm{Zn} \quad(\mathrm{ppm})$ & 10 & 12 & 14 & 17 & $11 *$ & 21 \\
\hline
\end{tabular}

* = Significantly different from dead tissue at $\alpha \leqslant 0.05$ level.

hand separated from the dead material. Samples for the live category were combined over two replicates within study areas, reducing the sample size to four for chemical analyses. The dead category was combined for each species over four replicates, reducing the sample size to two. All material was processed according to the procedures of the A.O.A.C. (1965). Analyses included: N, P, K, S, Mg, Ca, Mn, B, Cu, Zn, and ash. Statistical analyses for $t$-tests follow Snedecor and Cochran (1967).

\section{Results and Discussion}

Cattle were used as a grazing stress to determine if a change in mineral composition of the important forage plants would occur; however, the data showed no differences $(\alpha \leqslant 0.01)$ in mineral composition of plants, live or dead, after grazing. Severe grazing over longer time periods may produce different results. Since no differences were found due to grazing stress, the results of the mineral analyses were combined by treatments and presented by species in Table 1.

The live herbage for bluebunch wheatgrass was higher in $\mathrm{N}$, $\mathrm{P}, \mathrm{K}, \mathrm{Mg}$, and $\mathrm{B}$, as compared to the standing dead tissues.
Changes were not detected for $\mathrm{S}, \mathrm{Ca}, \mathrm{Na}, \mathrm{Mn}, \mathrm{Cu}$, and $\mathrm{Zn}$; but ash content was significantly lower in the live tissues. When considering all minerals, excluding ash, the live herbage was much higher in mineral composition than standing dead tissue. Cusick bluegrass also showed higher mineral values in live herbage than dead for all values except $\mathrm{Na}, \mathrm{Mn}, \mathrm{Cu}$, and $\mathrm{Zn}$, which were the same in both tissues. Ash was much lower in live herbage. Live tissues were higher in average mineral content than dead tissues. Live Thurber needlegrass was higher in $\mathrm{N}, \mathrm{K}$, and $\mathrm{B}$ in live than dead; lower values were evident in live herbage for $\mathrm{S}, \mathrm{Zn}$, and total ash. No changes were observed for $\mathrm{Mg}, \mathrm{Na}$, and $\mathrm{Mn}$. The transition from live to dead tissues in mineral composition was not so pronounced for Thurber needlegrass as with the other species.

Cusick bluegrass showed the highest mineral content of the three perennial grasses, followed by Thurber needlegrass and bluebunch wheatgrass. The $N$ and $P$ values reported for bluebunch wheatgrass compare favorably with those reported by Mcllvanie (1942), Stoddart (1946), and Church (1972). Apparently there are no published data concerning the mineral content of Cusick bluegrass or Thurber needlegrass from other rangeland areas in the western United States.

\section{Literature Cited}

Association of Official Agricultural Chemists. 1965. Official methods of analysis (10th ed.). Ass. Offic. Agr. Chem., Washington, D.C. 957 p.

Church, D. C. 1972. Digestive physiology and nutrition of ruminants. Oregon State Univ. Vol. 3, Practical Nutrition. $350 \mathrm{p}$.

Daubenmire, R. 1970. Steppe vegetation of Washington. Wash. Agr. Exp. Sta. Tech. Bull. 62.131 p.

Jameson, D. A. 1963. Response of individual plants to harvesting. Bot. Rev. 29:5 32-594.

Mcllvanie, S. K. 1942. Carbohydrates and nitrogen trends in bluebunch wheatgrass, Agropyron spicatum, with special reference to grazing influences. Plant Physiol. 17:540-557.

Rickard, W. H., D. W. Uresk, and J. F. Cline. 1975. Impact of cattle grazing on three perennial grasses in south-central Washington. J. Range Manage. 28:108-112.

Snedecor, G. W., and W. G. Cochran. 1967. Statistical methods. Sixth ed. Iowa State Univ. Press. 593 p.

Stoddart, L. A. 1946. Some physical and chemical responses of Agropyron spicatum to herbage removal at various seasons. Utah Agr. Exp. Sta. Bull. 324. 24 p. 